\title{
Contrasting bacterial and archaeal distributions reflecting different geochemical processes in a sediment core from the Pearl River Estuary
}

\author{
Wenxiu Wang ${ }^{1}$, Jianchang Tao ${ }^{2}$, Haodong Liư², Penghui Li², Songze Chen ${ }^{1}$, Peng Wang ${ }^{1 *}$ \\ and Chuanlun Zhang ${ }^{2,3^{*}}$ (D)
}

\begin{abstract}
Microbial community structure and metabolic activities have profound impacts on biogeochemical processes in marine sediments. Functional bacteria such as nitrate- and sulfate-reducing bacteria respond to redox gradients by coupling specific reactions amenable to relevant energy metabolisms. However, similar functional patterns have not been observed for sedimentary archaea (except for anaerobic methanotrophs and methanogens). We coupled taxonomic composition with comprehensive geochemical species to investigate the participation of distinct bacteria and archaea in sedimentary geochemical cycles in a sediment core $(300 \mathrm{~cm})$ from Pearl River Estuary (PRE). Geochemical properties $\left(\mathrm{NO}_{3}{ }^{-}\right.$, dissolved $\mathrm{Mn}$ and $\mathrm{Fe}, \mathrm{SO}_{4}{ }^{2+}, \mathrm{NH}_{4}{ }^{+}$; dissolved inorganic carbon (DIC), $\delta^{13} \mathrm{C}_{\mathrm{DIC}}$, dissolved organic carbon (DOC), total organic carbon (TOC), $\delta^{13} \mathrm{C}_{\mathrm{TOC}}$, and fluorescent dissolved organic matter (FDOM)) exhibited strong depth variability of different trends. Bacterial $16 \mathrm{~S}$ rRNA- and dsrB gene abundance decreased sharply with depth while archaeal and bathyarchaeotal $16 \mathrm{~S}$ rRNA gene copies were relatively constant. This resulted in an increase in relative abundance of archaea from surface (11.6\%) to bottom (42.8\%). Network analysis showed that bacterial groups of Desulfobacterales, Syntrophobacterales and Gammaproteobacteria were significantly $(\mathrm{P}<0.0001)$ associated with $\mathrm{SO}_{4}{ }^{2-}$ and dissolved Mn while archaeal groups of Bathyarchaeota, Group C3 and Marine Benthic Group D (MBGD) showed close positive correlations $(\mathrm{P}<0.0001)$ with $\mathrm{NH}_{4}{ }^{+}, \delta^{13} \mathrm{C}_{\mathrm{TOC}}$ values and humic-like FDOM. Our study suggested that these bacterial groups dominated in redox processes relevant to sulfate or metal oxides, while the archaeal groups are more like to degrade recalcitrant organic compounds in anaerobic sediments.
\end{abstract}

Keywords: Bacterial and archaeal communities, Depth variability, Geochemical cycles, Pearl River estuarine sediments

\section{Introduction}

Estuarine ecosystems are highly dynamic and one of the most productive environments due to enriched carbon

\footnotetext{
*Correspondence: pengwang@tongji.edu.cn; zhangcl@sustech.edu.cn ${ }^{1}$ State Key Laboratory of Marine Geology, Tongji University, Shanghai, China

${ }^{2}$ Shenzhen Key Laboratory of Marine Archaea Geo-Omics, Department of Ocean Science and Engineering, Southern University of Science and Technology, Shenzhen, China

Full list of author information is available at the end of the article
}

and nutrients (Cai 2011). Estuarine sediments usually harbor considerable microbial biomass and activities associated with the remineralization of sedimentary organic carbon, which has a significant impact on biogeochemical cycles (Burdige 2011). Geochemically, the depth sequence of oxidants used in the mineralization of organic matter is $\mathrm{O}_{2}, \mathrm{NO}_{3}{ }^{-}, \mathrm{Mn}(\mathrm{IV}), \mathrm{Fe}(\mathrm{III}), \mathrm{SO}_{4}{ }^{2-}$, and $\mathrm{CO}_{2}$ (Froelich et al. 1979); biologically, nitrate-, iron and manganese oxides- and sulfate-reducing bacteria are known to respond to redox gradients in the
Springer Open

(c) The Author(s) 2020. This article is licensed under a Creative Commons Attribution 4.0 International License, which permits use, sharing, adaptation, distribution and reproduction in any medium or format, as long as you give appropriate credit to the original author(s) and the source, provide a link to the Creative Commons licence, and indicate if changes were made. The images or other third party material in this article are included in the article's Creative Commons licence, unless indicated otherwise in a credit line to the material. If material is not included in the article's Creative Commons licence and your intended use is not permitted by statutory regulation or exceeds the permitted use, you will need to obtain permission directly from the copyright holder. To view a copy of this licence, visit http://creativeco mmons.org/licenses/by/4.0/. 
oxygen-depleted environments. Accordingly, bacterial community compositions can be linked to the vertical succession of predominant terminal electron acceptors (Algora et al. 2015; Walsh et al. 2016).

Archaeal groups responding to redox gradients in the sedimentary environments can be broadly characterized, with Marine Group I (ammonia-oxidizing archaea) occupying the surface or shallow oxic environments and Woesearchaeota perhaps the deeper anoxic environments (Dang et al. 2013; Nunoura et al. 2018). Although Bathyarchaeota and other uncultivated archaea are frequently found in anoxic sediments (Lazar et al. 2015; Zhou et al. 2018), only methanogens and methane-oxidizing archaea (ANMEs) can surely be defined as strict anaerobes, which are commonly present at or below the sulfate-methane transition zone (SMTZ) (Thauer et al. 2008). Most of the sedimentary archaea have resisted being brought into pure culture, which has kept their physiology and biogeochemical roles elusive.

Isotopic evidence from Peru margin has shown that the dominating sedimentary archaea may be heterotrophic (Biddle et al. 2006). Bathyarchaeota and Marine Benthic Group D (MBGD) exhibit high abundances in subsurface sediments and prefer low sulfide, high TOC conditions (Kubo et al. 2012; Lazar et al. 2015; Pan et al. 2019) or hydrate-bearing marine sediments (Inagaki et al. 2006), but their involvement in methane production or oxidation is controversial (Biddle et al. 2006; Kubo et al. 2012). Recent studies based on genomic analysis revealed a variety of metabolisms in uncultured archaea. These are exemplified by sulfur- or sulfate reduction in Hadesarchaeota, Thorarchaeota, Theionarchaea and Bathyarchaeota (Baker et al. 2016; Lazar et al. 2017; Seitz et al. 2016; Zhang et al. 2016), nitrate- or nitrite reduction in Hadesarchaeota, Bathyarchaeota and MBGD (Baker et al. 2016; Lazar et al. 2016; Zhou et al. 2018), methane and/or short alkane metabolism in Bathyarchaeota, Verstratearchaeota, Hadesarchaeota, Helarchaeota and other TACK superphylum archaea (Evans et al. 2015; Seitz et al. 2019; Vanwonterghem et al. 2016; Wang et al. 2019), and detrital protein degradation and acetogenesis in most of anaerobic archaea (He et al. 2016; Lazar et al. 2017; Lloyd et al. 2013). Lokiarchaeota may be capable of iron reduction in sediments of the Arctic mid-ocean ridge (Jorgensen et al. 2012; Sousa et al. 2016). A lokiarchaeon (Candidatus Promethearchaeum syntrophicum strain MK-D1) was firstly cultured from methane seep sediments, which was able to utilize amino acids in syntrophy with Methanogenium (Imachi et al. 2019).

To date, most of these predicted metabolisms have yet to be proven except three studies of enrichment and pure cultures (Imachi et al. 2019; Yu et al. 2018;
Vanwonterghem et al. 2016). Hence, more investigations are required to better understand the geochemical functions of uncultured archaea.

In this study, geochemical methods were used for quantifying and characterizing different chemical species, and molecular techniques with quantitative PCR (qPCR) and sequencing for different bacterial and archaeal populations along the depth of a 300-cm sediment core from eutrophic Pearl River Estuary (PRE). Large differences in distributional patterns of bacterial and archaeal groups as well as the functional genes were found along the environmental profile, allowing the differentiation of their potential roles involved in geochemical processes.

\section{Materials and methods}

\section{Sediment sampling}

A 300-cm gravity core was collected at 21-m water depth in PRE (22.1315 N, 113.8055 E) in October 2017. Sampling of pore water and sediment for geochemical and microbial analyses was conducted onboard the ship as quickly as possible. The core was sectioned into $5-\mathrm{cm}$ intervals for $0-100 \mathrm{~cm}$ and into $10-\mathrm{cm}$ intervals for $100-300 \mathrm{~cm}$ below sediment surface. DNA samples were snap-freezed in liquid nitrogen before storage at $-80^{\circ} \mathrm{C}$. Pore water was extracted with Rhizon samplers (Dickens et al. 2007). For sulfate measurements, 2 -ml pore water was acidified with $50 \% \mathrm{HCl}$ to remove volatile sulfur compounds and then stored at $4{ }^{\circ} \mathrm{C}$. For total dissolved $\mathrm{Mn}$ and Fe measurements, 2-ml pore water was acidified with $65 \% \mathrm{HNO}_{3}$ and then stored at $4{ }^{\circ} \mathrm{C}$. Pore water samples and sediment samples were also stored in a $-20{ }^{\circ} \mathrm{C}$ freezer; the former samples were used for analyses of dissolved inorganic carbon (DIC), dissolved organic carbon (DOC), fluorescent dissolved organic matter (FDOM) and nutrients, and the latter for total organic carbon (TOC).

\section{Geochemical analysis}

Sulfate concentrations were diluted (1:500) and measured on an ionic chromatograph (Dionex ICS-1500, USA). Total dissolved $\mathrm{Mn}$ and Fe levels were determined with an inductively coupled plasma atomic emission spectrometry. $\mathrm{NO}_{3}{ }^{-}$and $\mathrm{NH}_{4}{ }^{+}$were analyzed using an autoanalyzer (BRAN and LUEBBE AA3, Germany). Concentrations and carbon isotopic compositions of DIC were analyzed on a continuous-flow isotope ratio mass spectrometer (MAT 253, Gas Bench). The precision based on duplicate analysis was $\pm 0.2 \%$ for $\delta^{13} C_{\text {DIC }}$. Sediments for TOC analyses were freeze-dried and ground. TOC content was determined on an elemental analyzer (Vaio EL Cube, Germany) after acid dissolution of carbonates from an aliquot of dried sediment powder. Stable carbon isotopes of TOC $\left(\delta^{13} \mathrm{C}_{\mathrm{TOC}}\right)$ were measured using 
a Thermo Science Delta Plus isotope ratio mass spectrometer connected on-line to a Carlo Erba Instruments Flash 1112 elemental analyzer. The analytical precision was $\pm 0.1 \%$ for TOC content and $\pm 0.2 \%$ for $\delta^{13} C_{\text {TOC }}$.

\section{Spectroscopic analysis and parallel factor analysis (PARAFAC) for DOM}

Spectroscopic analysis of DOM samples (GSD-110 and GSD-270 were not included) was conducted on a fluorescence spectrometer (Jobin-Yvon Horiba Aqualog-800-C, Horiba Instruments). Fluorescence excitation-emission matrix (EEM) spectra were generated from 240 to $450 \mathrm{~nm}$ at $2 \mathrm{~nm}$ increments for excitation (Ex) wavelengths, and from 245.90 to $829.35 \mathrm{~nm}$ at $1.17 \mathrm{~nm}$ increments for emission (Em) wavelengths. All the sample spectra were normalized to Raman peak area after corrected with the ultrapure water EEM spectra, and reported in Raman unit (R.U.) (Murphy 2011). Finally, parallel factor analysis (PARAFAC) was carried out in MATLAB 2013 (Mathworks, USA) with the DOM Fluor toolbox (http://www. models.life.ku.dk).

\section{DNA extraction, qPCR and amplicon sequencing}

DNA was extracted from 0.2 to $0.3 \mathrm{~g}$ of sediment (wet weight) using a PowderSoil DNA Isolation kit (Mo Bio) according to the instruction and stored at $-20{ }^{\circ} \mathrm{C}$ until further analyses. Targeted genes for qPCR analyses included 16S rRNA genes for bacteria, archaea, Bathyarchaeota; $d s r B$ gene for sulfate-reducing bacteria (SRB), nirS gene for denitrifying bacteria; $m c r A$ gene for methanotrophic and methanogenic archaea. The primers and standards used in this study are shown in Additional file 1: Table S1. The qPCR analyses were performed on a QuantStudio 5 Real-Time PCR System and the reaction volume was $10 \mu \mathrm{l}: 5 \mu \mathrm{l}$ of SYBR Premix Ex Taq ${ }^{\mathrm{TM}}$ II (TaKaRa), $0.4 \mu \mathrm{M}$ of each primer, $0.1 \mu \mathrm{l}$ of $1 \%$ bovine serum albumin (BSA), $0.2 \mu \mathrm{l}$ of ROXII (TaKaRa), $2.9 \mu \mathrm{l}$ of $\mathrm{ddH}_{2} \mathrm{O}$ and $1 \mu \mathrm{l}$ of template DNA. The amplification conditions were as follows: $30 \mathrm{~s}$ denaturation at $95^{\circ} \mathrm{C}$ and 40 cycles of denaturation at $95^{\circ} \mathrm{C}$ for $5 \mathrm{~s}$, annealing at $55^{\circ} \mathrm{C}$ for $45 \mathrm{~s}$ and extension at $72{ }^{\circ} \mathrm{C}$ for $1 \mathrm{~min}$. The linear correlation coefficients $\left(R^{2}\right)$ ranged from 0.99 to 1.00 , and the amplification efficiencies were between 90 and $110 \%$.

The V4 region of the prokaryotic 16S rRNA gene was PCR amplified with universal prokaryotic primers 515FB (GTGYCAGCMGCCGCGGTAA) and 806RB (GGACTA CNVGGGTWTCTAAT) (Caporaso et al. 2012). The $50 \mu \mathrm{l}$ of PCR mixture consisted of $25 \mu \mathrm{l}$ of $2 \times$ Premix Taq DNA polymerase (TaKaRa), $0.2 \mathrm{mM}$ of each primer, $20 \mu \mathrm{l}$ of $\mathrm{dd}_{2} \mathrm{O}$, and $3 \mu \mathrm{l}$ of template DNA. Procedures for the PCR were as follows: $30 \mathrm{~s}$ denaturation at $94{ }^{\circ} \mathrm{C}, 30 \mathrm{~s}$ annealing at $58{ }^{\circ} \mathrm{C}$ and $30 \mathrm{~s}$ extension at $72{ }^{\circ} \mathrm{C}$, repeated for 30 cycles in a BioRad S1000 (Bio-Rad Laboratory,
CA). The PCR products were pooled and purified using the EZNA Gel Extraction Kit (Omega, USA). Sequencing was conducted on the Miseq platform $(2 \times 250 \mathrm{PE}$, lllunina) at the Guangzhou Magigene Biotechnology (Guangzhou, China).

Raw Miseq data were analyzed using the Quantitative Insights into Microbial Ecology (Qiime2, version 2018.4) with plugins demux, DADA2 and feature-table. Features with a total abundance of less than 10 and those present in only a single sample were filtered out. Sequence Taxonomy was assigned using the Silva 128 99\% Operational Taxonomic Units (OTUs) database (https://www.arbsilva.de/ngs). Shannon diversity index was calculated for alpha diversity analysis.

\section{Statistical analysis}

Principal coordinates analysis (PCoA) was used to evaluate the compositional changes of microbial community based on Bray-Curtis distance. Species tables are normalized and square root transformed before PCoA and analysis of the similarity (ANOSIM) performed in PRIMER software package (Clarke and Gorley 2006). Linear discriminant analysis (LDA) effect size (LEfSe) (Segata et al. 2011) was used to identify microbial populations with significant difference between upper and deep layers. Spearman correlations between the relative abundance of OTUs and environmental parameters were conducted in R 3.5.0, and performed in network by Cytoscape 3.6.1 (Shannon et al. 2003). OTUs related to environmental parameters were selected to build a Maximum-likelihood (ML) phylogenetic tree with their reference sequences from different sampling sites using MEGA 7.0 (Kumar et al. 2016).

\section{Sequencing results and deposition}

Source sequences are available in the GenBank nucleotide sequence database under the Accession number PRJNA575161.

\section{Results \\ Geochemistry of pore water and sediments}

Geochemical profiles were described in the order of nitrate reduction, $\mathrm{Mn} / \mathrm{Fe}$ reduction, and sulfate reduction (Fig. 1). $\mathrm{NO}_{3}{ }^{-}$maintained high concentrations at all depths, making the nitrogenous zone ambiguous. Total dissolved Mn followed a typical diagenetic profile and reached maximum at $75-\mathrm{cm}$ depth. Total dissolved Fe increased in the deep layers as dissolved Mn decreased, probably defining the shift from the manganous zone to the ferruginous zone. $\mathrm{SO}_{4}{ }^{2-}$ decreased linearly from $\sim 25$ to $\sim 3 \mathrm{mM}$ in the upper $150 \mathrm{~cm}$ and then increased temporarily before staying at $\sim 9 \mathrm{mM}$ until the bottom depth $(300 \mathrm{~cm})$. The drop in sulfate concentration from surface 


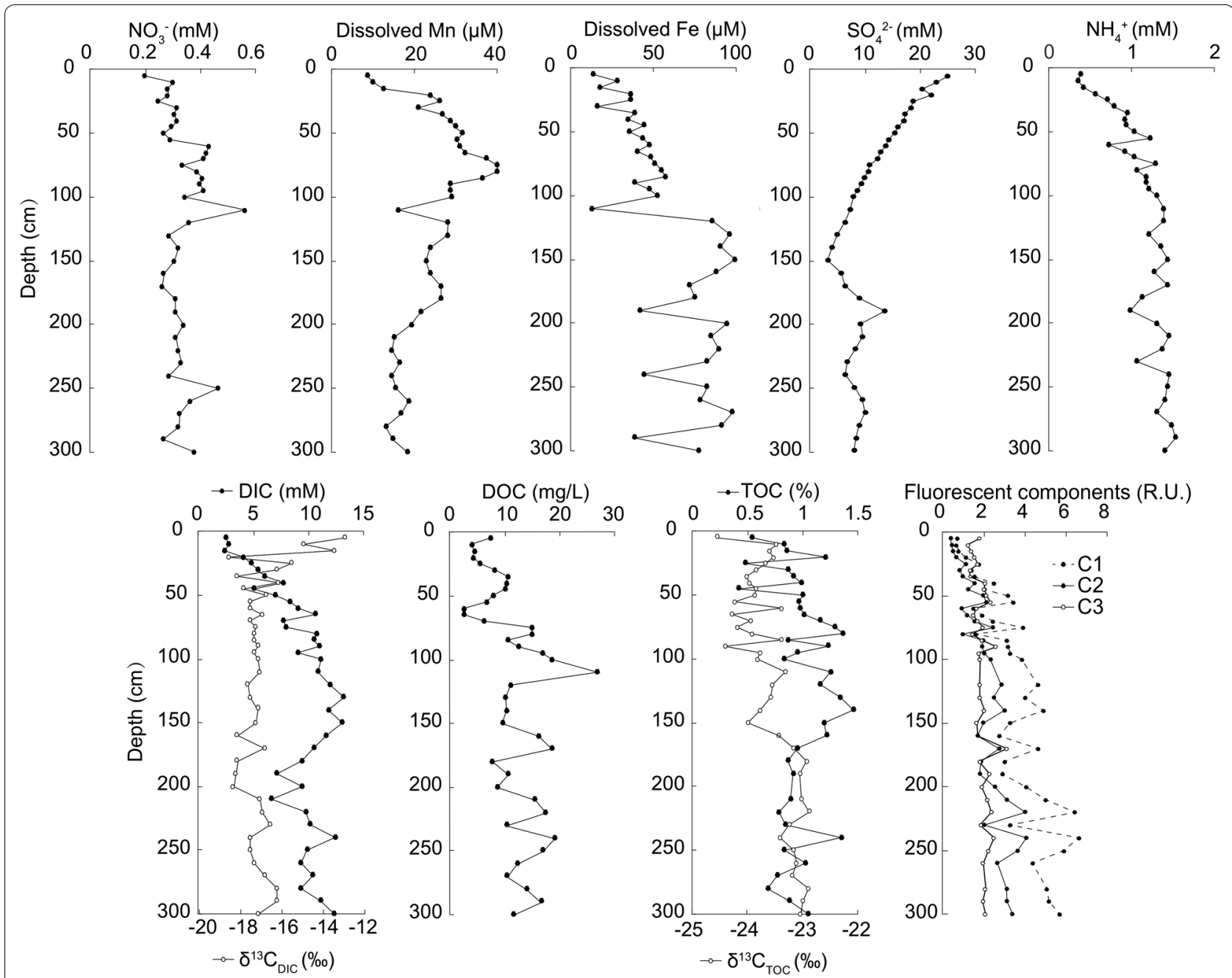

Fig. 1 Characteristics of pore water chemistry $\left(\mathrm{NO}_{3}{ }^{-}, \mathrm{NH}_{4}{ }^{+}\right.$, dissolved $\mathrm{Mn}, \mathrm{Fe}$, and $\mathrm{SO}_{4}{ }^{2-}$, DIC, DOC, and fluorescent components) and sediment total organic carbon (TOC). Collection of pore water for geochemical analyses was conducted onboard the ship as quickly as possible using Rhizon samplers

value indicated an overall occurrence of microbial sulfate reduction within the sediment core. Dissolved oxygen was not determined.

$\mathrm{NH}_{4}^{+}$gradually increased down-core from $\sim 0.4 \mathrm{mM}$ to higher than $1 \mathrm{mM}$. DIC and DOC concentrations increased downward and peaked at $\sim 12 \mathrm{mM}$ at 150$\mathrm{cm}$ depth and $\sim 27 \mathrm{mg} / \mathrm{l}$ at $110-\mathrm{cm}$ depth, respectively. $\delta^{13} C_{\text {DIC }}$ values decreased down-core to a range between -18.6 and $-13.0 \%$. Keeling plot analysis of DIC showed $\delta^{13} \mathrm{C}$ values of around $-18.4 \%$ for excess DIC (Additional file 2: Fig. S1), implying that the accumulation of DIC was mainly derived from the respiration of organic matter. TOC content varied between 0.4 and $1.5 \%$ along the core. $\delta^{13} \mathrm{C}_{\mathrm{TOC}}$ values ranged from -24.5 to $-22.8 \%$ o and showed difference below and above $150-\mathrm{cm}$, indicating a minor change of organic matter from marine plankton-derived to terrestrial plants-derived (Wu et al. 1999).

\section{PARAFAC components of DOM}

Three different PARAFAC components were identified, including two humic-like components ( $\mathrm{C} 1$ and $\mathrm{C} 2)$ and one protein-like component (C3). Both $\mathrm{C} 1$ and $\mathrm{C} 2$ were identified as a combination of two EEM peaks (peak A and peak $\mathrm{M}$ for $\mathrm{C} 1$, peak $\mathrm{A}$ and peak $\mathrm{C}$ for $\mathrm{C} 2$; Additional file 3: Table S2). Peak A and peak $C$ are depicted as terrestrially derived humic substances and peak $M$ as the marine humic-like substances or products from microbial processes (Coble 1996; Stedmon and Markager 2005). C3 exhibiting its emission maxima at $307 \mathrm{~nm}$ and its excitation maxima at $274 \mathrm{~nm}$, corresponded to tyrosine-like and/or protein-like substances (peak B; Additional file 3: 
Table S2) (Coble 1996). Overall, humic-like component C1 was the most abundant fraction (45.0\%), followed by humic-like component $\mathrm{C} 2(27.7 \%)$ and protein-like component C3 (27.3\%). C1, C2 and C3 varied differently from each other with increasing depth (Fig. 1). Humiclike components ( $\mathrm{C} 1$ and $\mathrm{C} 2)$ showed marked increases downward, while the protein-like component (C3) was relatively constant.

\section{Distributions of bacterial and archaeal abundances}

The bacterial 16S rRNA and $d s r B$ gene abundances decreased from $7.03 \times 10^{9}$ to $3.92 \times 10^{8}$ copies $/ g$ sediments and from $4.05 \times 10^{8}$ copies/g sediments to $1.41 \times 10^{7}$ copies/g sediments, respectively (Fig. 2). The bacterial $16 \mathrm{~S}$ rRNA and $d s r B$ gene copies were in the same range with those reported in the eutrophic PRE (Jiang et al. 2009). Both of them sharply declined with sediment depth. Besides, bacterial abundance was strongly, negatively correlated to $\delta^{13} \mathrm{C}_{\mathrm{TOC}}(\mathrm{r}=-0.75$, $\mathrm{P}<0.0001)$, and positively correlated to the $\mathrm{C} 3 /(\mathrm{C} 1+\mathrm{C} 2)$ ratio $(\mathrm{r}=0.76, \mathrm{P}<0.0001)$. DsrB gene abundance also exhibited high correlation with $\mathrm{SO}_{4}{ }^{2-}(\mathrm{r}=0.82$, $\mathrm{P}<0.0001), \delta^{13} \mathrm{C}_{\mathrm{TOC}}(\mathrm{r}=-0.70, \mathrm{P}<0.0001)$ and the $\mathrm{C} 3 /$ $(\mathrm{C} 1+\mathrm{C} 2)$ ratio $(\mathrm{r}=0.80, \mathrm{P}<0.0001)$. The abundances of nirS gene and $m c r A$ gene were much lower than $d s r B$ gene at all depths (data not shown).

Archaeal and bathyarchaeotal 16S rRNA gene abundances varied differently from that of bacteria along the depth (Fig. 2). Archaeal and bathyarchaeotal 16S rRNA gene abundances showed a slight increase down core, with the maximum of $1.75 \times 10^{9}$ copies/g sediments at $110-\mathrm{cm}$ and $2.30 \times 10^{8}$ copies/g sediments at $110-\mathrm{cm}$ and $160-\mathrm{cm}$ depth, respectively. The archaea-to-bacteria abundance ratios increased from 0.19 at $5-\mathrm{cm}$ depth to 2.51 at $300-\mathrm{cm}$ depth, which were higher than that previous reported in PRE (Jiang et al. 2011) and in South China Sea (Yu et al. 2017).

\section{Distributions of the most abundant bacterial and archaeal phyla}

Illumina sequencing of 38 sediment samples (GSD250 and GSD-270 were not included) yielded a total of 2,580,094 high-quality sequences after quality control, ranging from 47,995 to 83,260 reads in each sample. Sequence numbers in each sample reduced to 38,887 after rarefaction for further analyses. Those sequences covered the diversity of microbial populations in samples as Shannon diversity indices reached stable values (Additional file 2: Fig. S2). In total, 5553 OTUs were generated on the basis of $100 \%$ sequence identity, including 4164 for

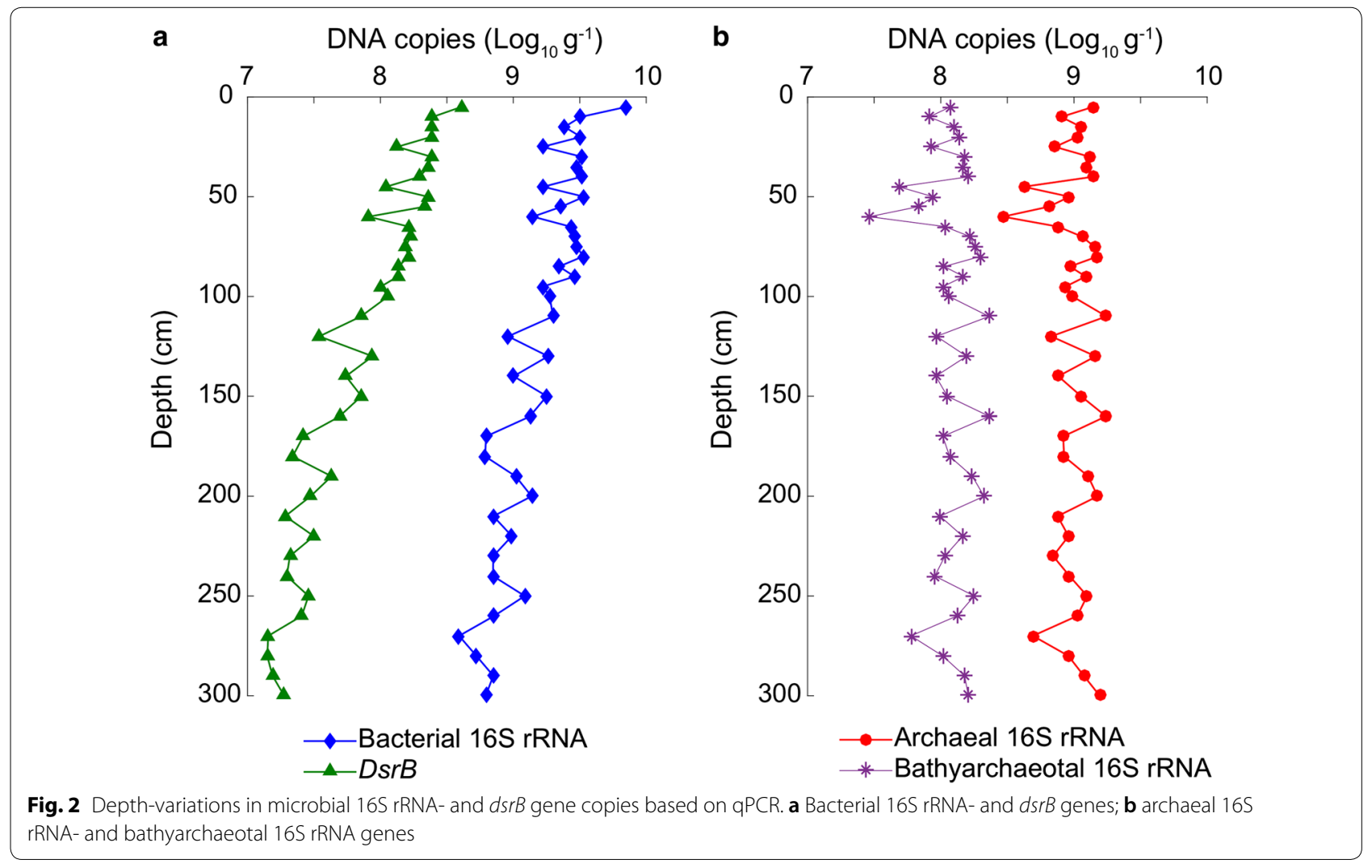


bacteria, 1268 for archaea and 121 as unassigned OTUs. The bacterial and archaeal OTUs were classified into 47 and 17 phyla, respectively. Ten of 47 bacterial phyla and five of 17 archaeal phyla had relative abundances of $>1 \%$.

Proteobacteria, Chloroflexi, Planctomycetes and Nitrospirae were the top four bacterial phyla (Fig. 3a). The great majority of Proteobacteria could be assigned to
Desulfobacterales, Desulfarculales, Syntrophobacterales (three orders of Deltaproteobacteria) and Gammaproteobacteria. All of them decreased with depth and exhibited significantly positive correlations with $\mathrm{SO}_{4}{ }^{2-}$ in pore water $(r>0.80, \mathrm{P}<0.0001$ of all) except for Desulfarculales that increased slightly and showed a positive correlation with $\delta^{13} \mathrm{C}_{\mathrm{TOC}}(\mathrm{r}=0.74, \mathrm{P}<0.0001)$. Anaerolineae and
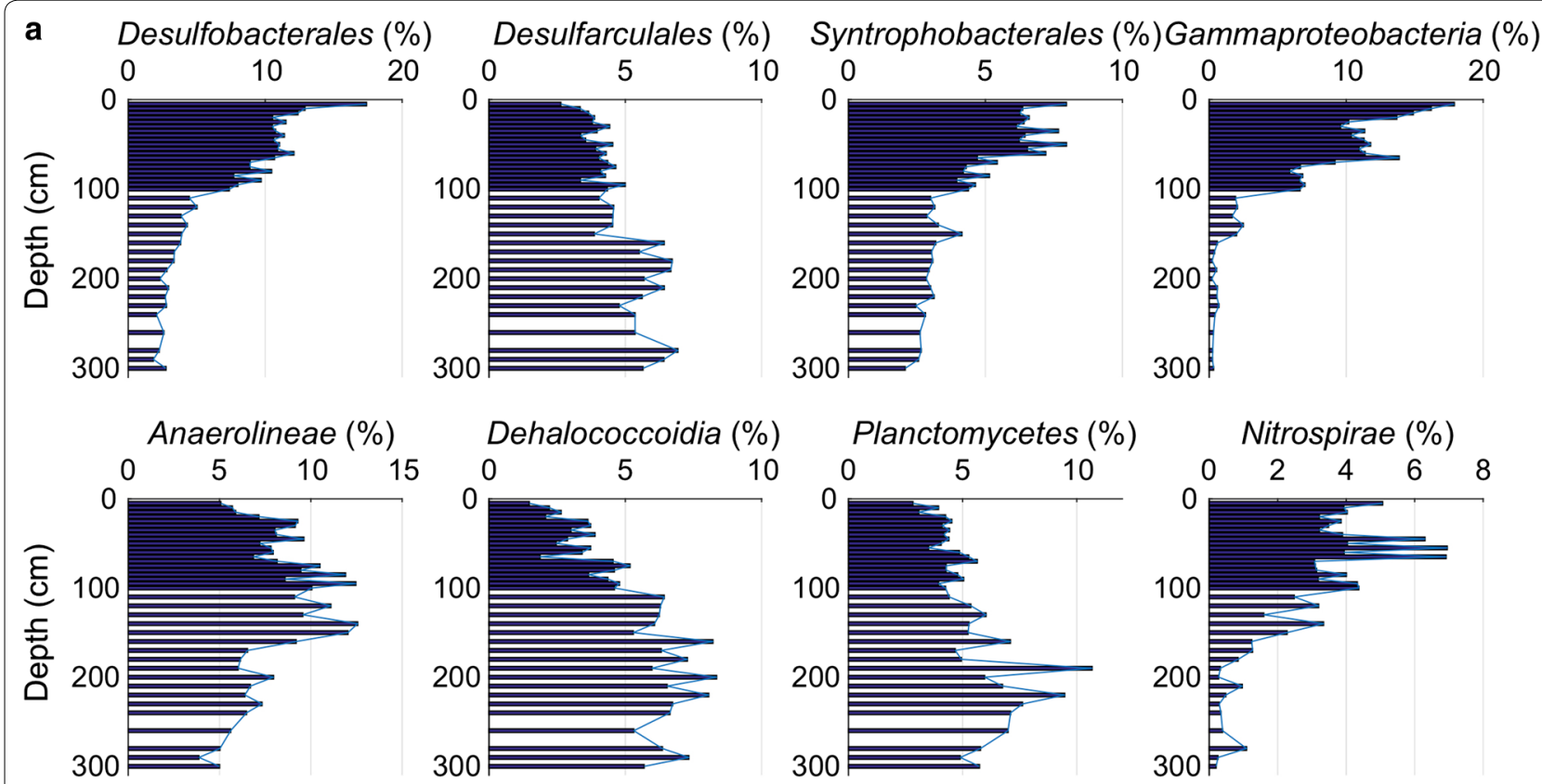

b
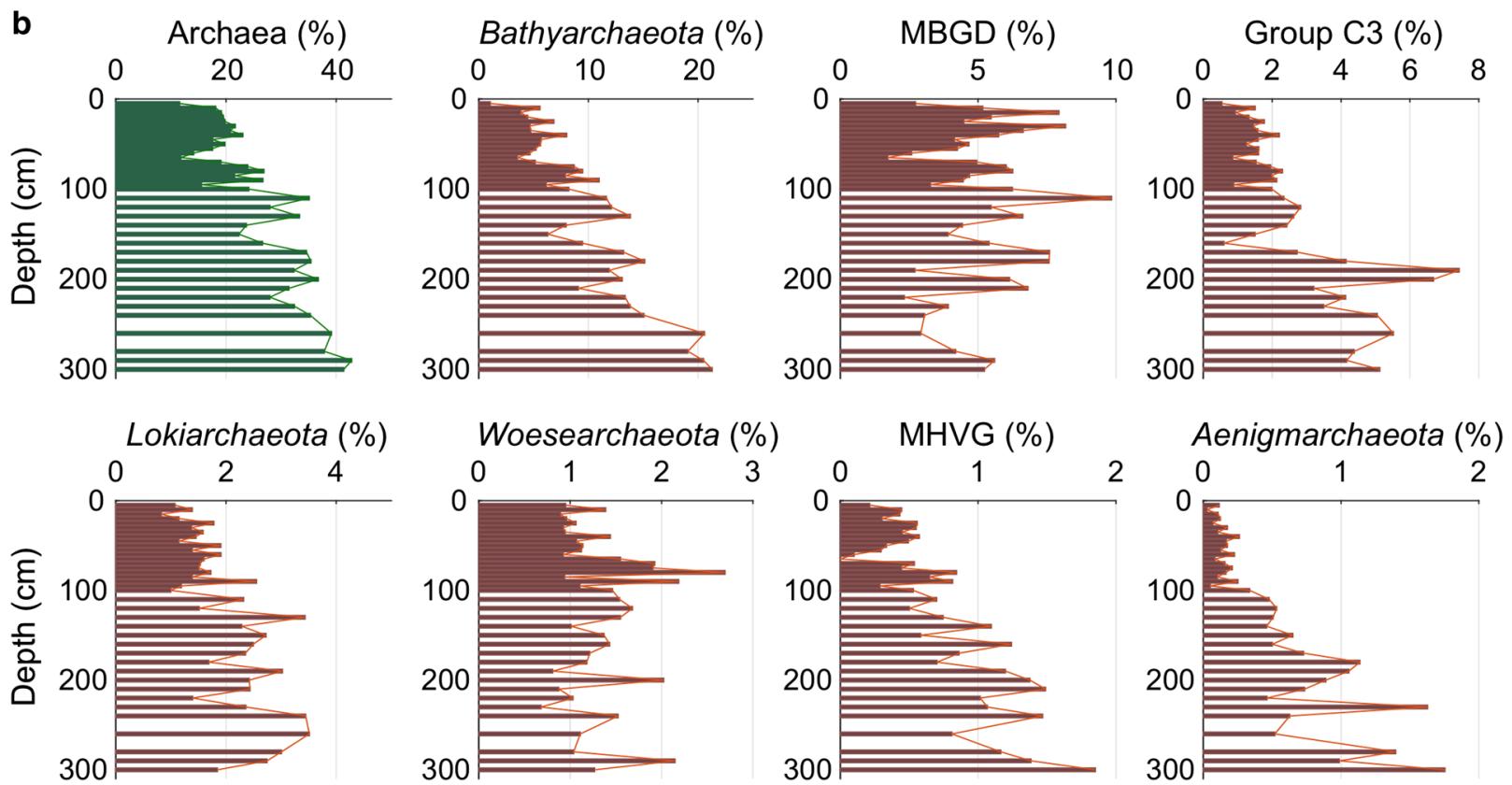

Fig. 3 Depth distributions of relative abundances of bacteria (a) and archaea (b). Dark blue = bacterial groups, green $=$ total archaea and dark red $=$ different archaeal groups 
Dehalococcoidia were two major classes of Chloroflexi. All reads of Anaerolineae were affiliated to the family Anaerolineaceae, exhibiting a depth profile with the relative abundance decreased after reaching its maximum at $140-\mathrm{cm}$ depth. The relative abundance of Dehalococcoidia increased down-core and showed positive correlation with $\mathrm{NH}_{4}^{+}(\mathrm{r}=0.76, \mathrm{P}<0.0001)$. In addition, an increase in the relative abundance of Planctomycetes was coincided with relatively decrease of Nitrospirae, both of which were known to potentially involve in the nitrogen cycle (Schmid et al. 2003; Ushiki et al. 2017).

The main archaeal groups included Bathyarchaeota, Group C3 (affiliated to Bathy-15), MBGD (a family of Euryarchaeota), Lokiarchaeota, Woesearchaeota, Marine Hydrothermal Vent Group (MHVG) and Aenigmarchaeota (Fig. 3b). The relative abundance of Bathyarchaeota increased by about 20-folds (from 1.06 to $21.3 \%$ ), and showed positive correlations with $\mathrm{NH}_{4}{ }^{+}$and $\delta^{13} \mathrm{C}_{\mathrm{TOC}}$ values $(r=0.68, P<0.0001$ of both). Similar depth profiles also appeared in Lokiarchaeota, MHVG and Aenigmarchaeota, while MBGD and Woesearchaeota seemed to be constant with depth. The relative abundance of Group C3 exhibited a depth profile with a sharp increase below 150$\mathrm{cm}$ depth. In general, the relative abundance of archaea increased from 11.6 to $42.8 \%$ and showed strong positive relationship with the content of humic-like FDOM $(\mathrm{C} 1+\mathrm{C} 2)(\mathrm{r}=0.72, \mathrm{P}<0.0001)$.

PCoA of microbial abundance showed clustering of samples along the depth (GSD-5 to GSD-100, GSD110 to GSD-200, GSD-210 to GSD-300) (Fig. 4a). The PCo1 (PCo1 explained $84.0 \%$ of the variance) showed high correlations with $\mathrm{SO}_{4}{ }^{2-}(\mathrm{r}=0.72, \mathrm{P}<0.0001)$, $\mathrm{NH}_{4}{ }^{+}(\mathrm{r}=-0.75, \mathrm{P}<0.0001)$, dissolved $\mathrm{Fe}(\mathrm{r}=-0.66$, $\mathrm{P}<0.0001), \quad \delta^{13} \mathrm{C}_{\mathrm{TOC}}$ values $\quad(\mathrm{r}=-0.72, \quad \mathrm{P}<0.0001)$, humic-like FDOM $(\mathrm{C} 1+\mathrm{C} 2) \quad(\mathrm{r}=-0.77, \mathrm{P}<0.0001)$. Next, LEfSe confirmed the tendency that most of the archaeal groups and Dehalococcoidia, Desulfarculales and Planctomycetes were significantly abundant in deep layers, whereas Gammaproteobacteria, Desulfobacterales, Nitrospirae, Syntrophobacterales and Anaerolineae were more abundant in the upper layers (Fig. $4 \mathrm{~b}$ ).

\section{Specific linkages between environmental variables and bacterial or archaeal species revealed by network analysis}

To further investigate the impacts of geochemical factors on the distribution of microbial populations, the top 100 OTUs of the eight bacterial groups and the top 100 OTUs of the seven archaeal groups (Additional file 4: Table S3) were selected to analyze their correlations with geochemical factors. These OTUs accounted for $38.4 \%$ of the total sequences. Network analysis was conducted based on positive Spearman correlation
( $\rho>0.65, \mathrm{P}<0.0001)$ and consisted of 79 nodes and 123 edges (Fig. 5). Geochemical parameters were roughly divided into two groups with different edge colors, grey for electron acceptors-related variables $\left(\mathrm{SO}_{4}{ }^{2+}, \mathrm{NO}_{3}{ }^{-}\right.$, dissolved $\mathrm{Mn}$ and $\mathrm{Fe}, \mathrm{DIC}$, and $\delta^{13} \mathrm{C}_{\mathrm{DIC}}$ ) and orange for electron donors-related variables $\left(\mathrm{NH}_{4}^{+}, \mathrm{DOC}, \mathrm{TOC}\right.$, $\delta^{13} \mathrm{C}_{\mathrm{TOC}}, \mathrm{C} 1, \mathrm{C} 2$ and $\mathrm{C} 3$ ).

$\mathrm{SO}_{4}{ }^{2-}$ exhibited close correlations with OTUs belonging to Syntrophobacterales, Desulfobacterales and Gammaproteobacteria. Two OTUs of MBGD and one of Bathyarchaeota also correlated with $\mathrm{SO}_{4}{ }^{2-}$. Dissolved Mn showed positive correlations with four OTUs belonging to Desulfobacterales, Syntrophbacterales and Bathyarchaeota, while dissolved Fe was more closely related to OTUs that were affiliated to Dehalococcoidia, Anaerolineae and Planctomycetes. This result was different from the findings in San Pedro Basin (Monteverde et al. 2018) where dissolved Fe exhibited close positive correlations with proteobacterial OTUs. Bacterial or archaeal OTUs showed few direct correlations with DOC and DIC, but were closely correlated to $\delta^{13} \mathrm{C}_{\mathrm{TOC}}$ and $\mathrm{NH}_{4}{ }^{+}$. Moreover, eighteen archaeal OTUs belonging to Bathyarchaeota, Group C3, MBGD and Lokiarchaeota and seven bacterial OTUs belonging to Dehalococcoidia, Anaerolineae and Desulfarculales were positively correlated with $\mathrm{C} 1$ and $\mathrm{C} 2$. Notably, more archaeal OTUs were related to electron donors than electron acceptors.

\section{Phylogenetic analysis of 16S rRNA gene}

A total of 72 OTUs significantly related to geochemical factors (Spearman, $\rho>0.65, \mathrm{P}<0.0001$ ) were used for phylogenetic analysis, in which 44 belonged to bacteria (Fig. 6a) and 28 to archaea (Fig. 6b). The ML phylogenetic trees indicated that homologous sequences of the bacteria and archaea from Pearl River estuarine sediments were similar to those found in sediments in west coast of India, Aarhus Bay, White Oak River (WOR) estuary, East China Sea, Taiwan gas hydrate potential area and Shimokita Penninsula offshore. Five OTUs of Anaerolineae, Planctomycetes, Deltaproteobacteria and Gammaproteobacteria and one of Bathyarchaeota were similar to sequences derived from sulfate reduction zone (SRZ) of sediments from Aarhus Bay (Starnawski et al. 2017). Two OTUs of MBGD and two of Bathyarchaeota exhibited high affinity to that from SRZ or SMTZ of sediments from WOR (Lazar et al. 2015) or anaerobic cultivation of sediments from WOR (Gagen et al. 2013). In addition, three OTUs of Bathyarchaeota were similar to those reported in methanogenic zone of hydrate-bearing environment (Lai et al. 2011). 


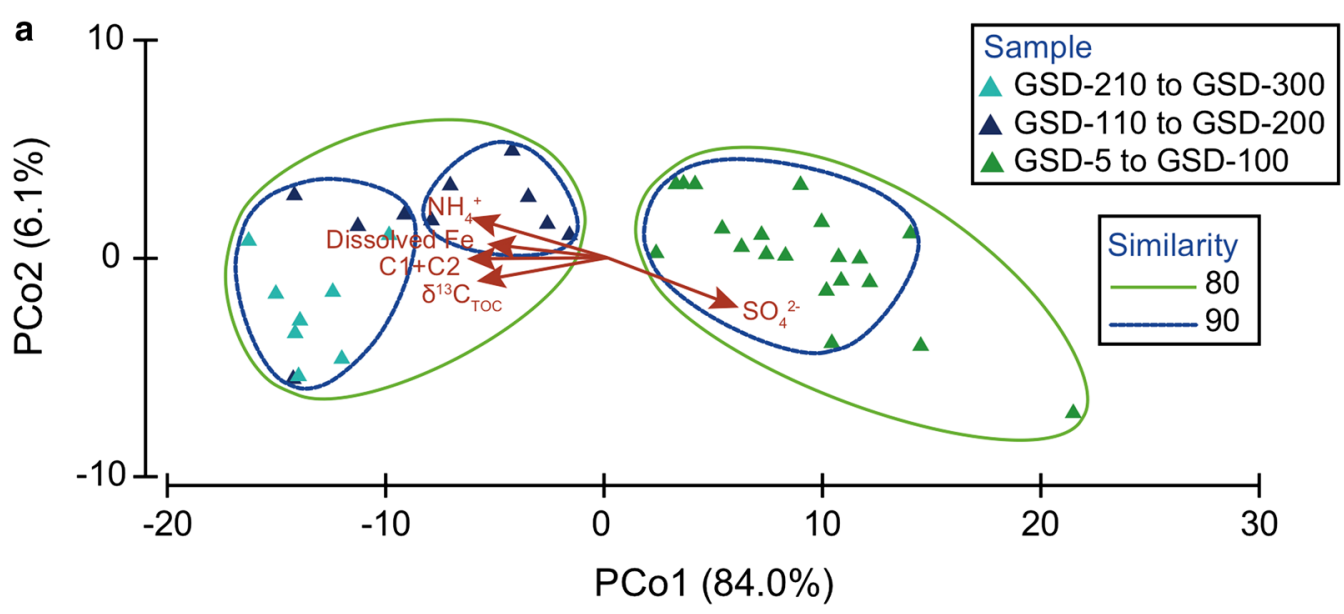

b
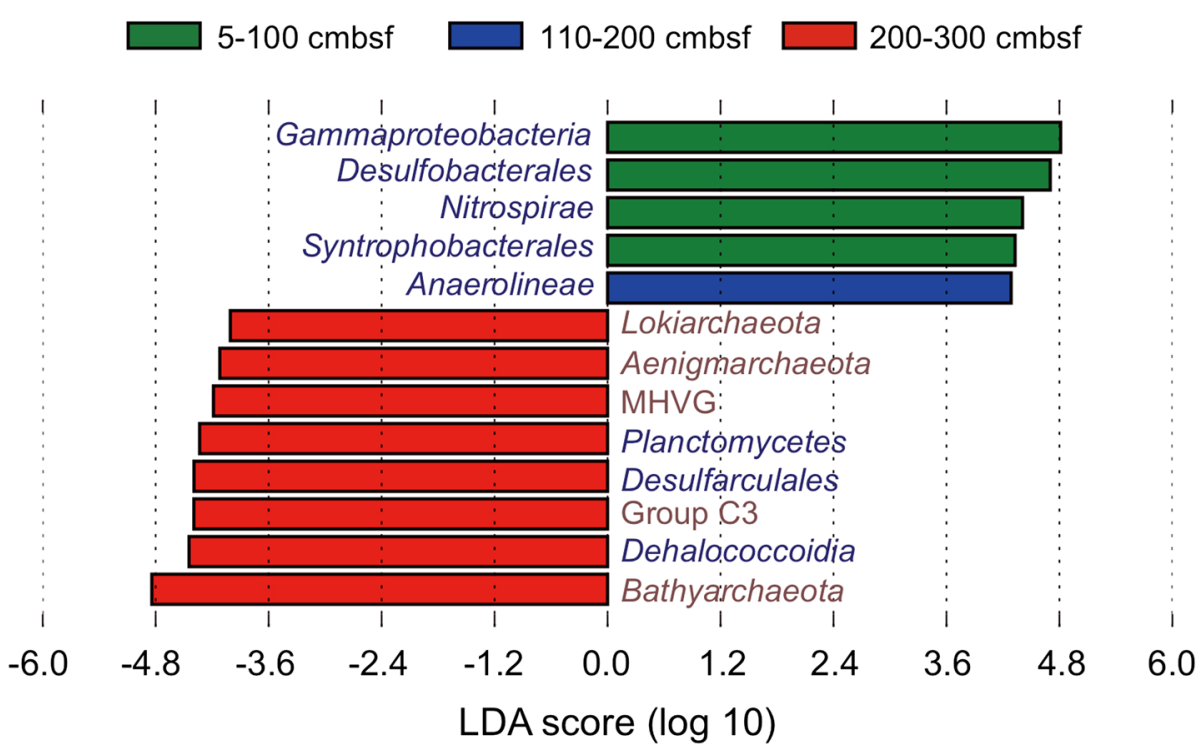

Fig. 4 Principal coordinates analysis (PCOA) (a) and linear discriminant analysis (LDA) effect size (LEfSe) of microbial groups (b) with a LDA threshold of 3.5. In (b), dark red = archaeal groups and dark blue= bacterial groups

\section{Discussion}

Though uncultured archaea have been reported widely from marine sediments (Inagaki et al. 2006; Jorgensen et al. 2012; Kubo et al. 2012; Lazar et al. 2015), their geochemical functions remain unclear. In this study, depth distributions of archaeal groups in absolute and relative abundances were compared to bacterial groups, and the differences may indicate their distinct roles in geochemical cycles.

Organiclastic sulfate reduction appeared to be the main remineralization process in the sediment core, overlapped by manganese oxide reduction above 100$\mathrm{cm}$ depth and iron oxide reduction in the sediments below 100-cm depth. The total bacterial and SRB abundances exponentially decreased with sediment depth, corresponding to the transition from oxic state to anoxic state and to the reduced available substrates, which was consistent with universal distributions (Kallmeyer et al. 2012; Roy et al. 2012). Microbial abundance was significantly correlated to TOC content in sediment cores from the South China Sea, Peru margin, Nankai trough, Black sea and Equatorial Pacific (Lipp et al. 2008; Yu et al. 2017). The source and composition of organic matter may also affect the abundance of benthic bacteria (Qiao et al. 2018). In this study, higher bacterial abundance in the upper layers may benefit from terrestrial plants-derived (lower $\delta^{13} \mathrm{C}_{\mathrm{TOC}}$ values) and protein-like organic matter (higher $\mathrm{C} 3 /(\mathrm{C} 1+\mathrm{C} 2)$ ratio). The abundance of SRB was significantly affected by $\mathrm{SO}_{4}{ }^{2-}$ in pore water $(\mathrm{r}=0.82$, $\mathrm{P}<0.0001)$ as expected. No significant correlation was 


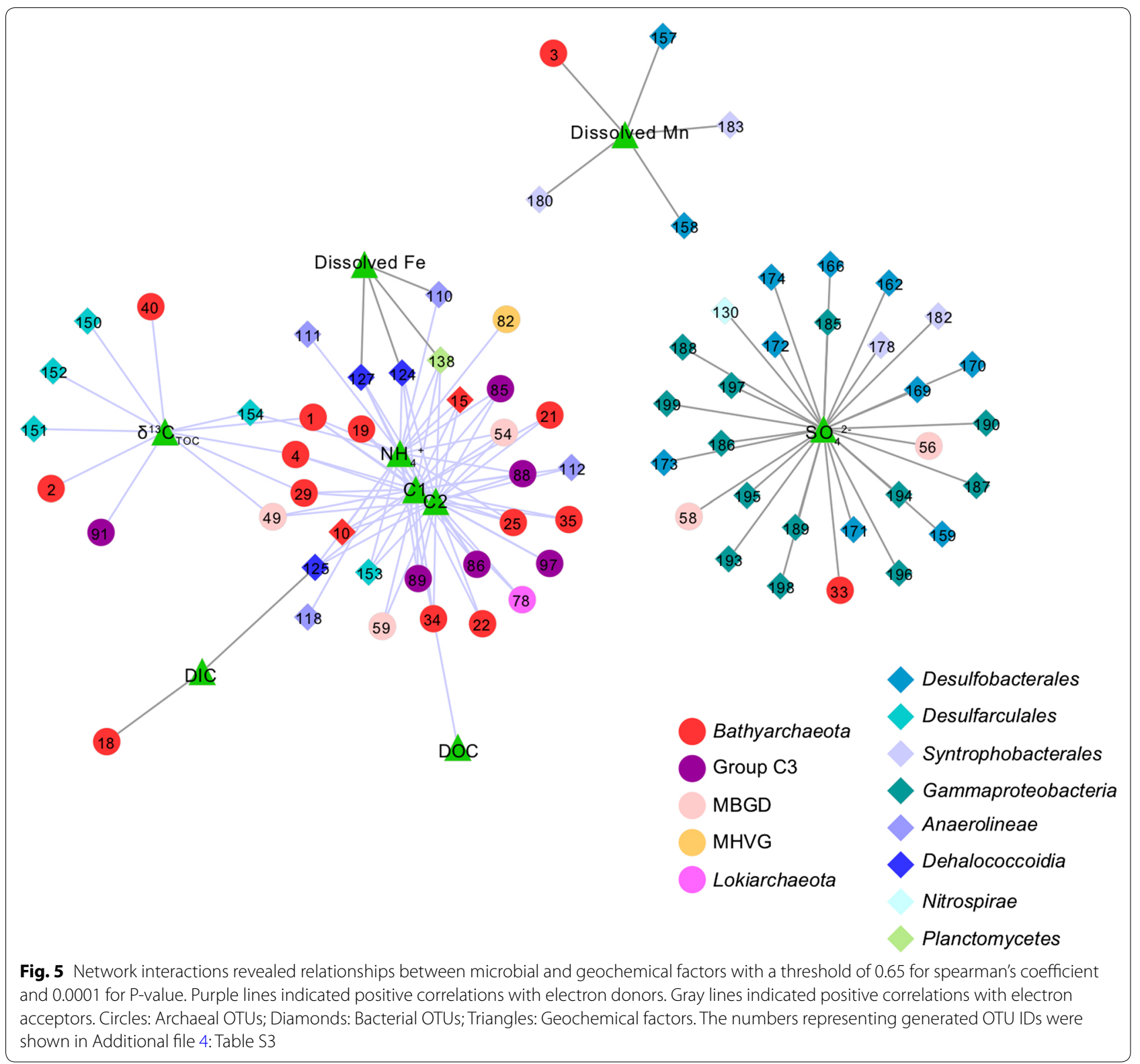

found between archaeal abundance and measured geochemical parameters. Archaeal groups may not depend on availabilities of labile organic matter or sulfate, which distinguished their vertical variability from that of bacteria (Fig. 2).

Organic matter availability coupled with metabolism of $\mathrm{Fe} / \mathrm{Mn}$ and sulfate reduction can shape bacterial community patterns in various ways, resulting in different depth profiles of bacterial groups (Figs. 4b, 5). Desulfobacterales, Syntrophobacterales and Gammaproteobacteria positively corresponded to the sulfate pore-water profile, implying their active roles in the sulfur cycle (Oni et al. 2015a; Orsi et al. 2013). On the other hand,
Deltaproteobacteria, Chloroflexi and Planctomycetes appeared to relate to metal oxides-reducing metabolisms (Fig. 5).

Bacterial groups such as Anaerolineaceae, Dehalococcoidia and Desulfarculales have been linked to the degradation of recalcitrant organic compounds (Oni et al. 2015b). They were mainly present in the deep layers in previous studies (Monteverde et al. 2018; Qiao et al. 2018) and showed positive correlations with $\mathrm{NH}_{4}{ }^{+}, \delta^{13} \mathrm{C}_{\mathrm{TOC}}$ values and humic-like FDOM in this study (Fig. 5). Anaerolineaceae were capable of degrading alkanes (Liang et al. 2015) under methanogenic conditions and members of the Dehalococcoidia or Desulfarculales were able of growing via diverse organohalide or aromatic 


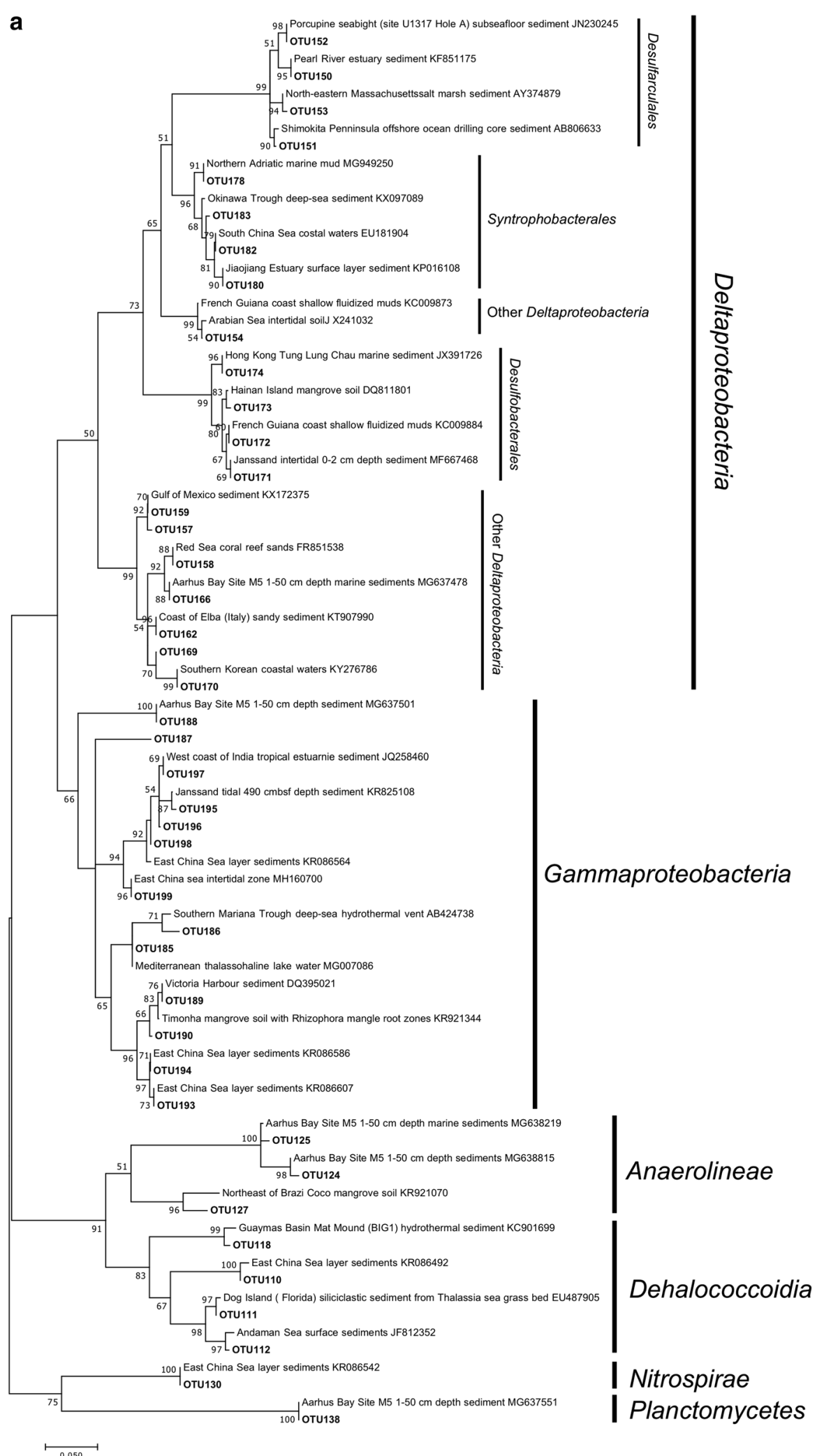

Fig. 6 The maximum likelihood tree of 165 rRNA gene sequences showing the phylogenetic affiliations of the bacterial (a) and archaeal (b) OTUs significantly related to geochemical factors (Spearman, $\rho>0.65, \mathrm{P}<0.0001$ ). MHVG marine hydrothermal vent group. MBGD marine benthic group $B$ 


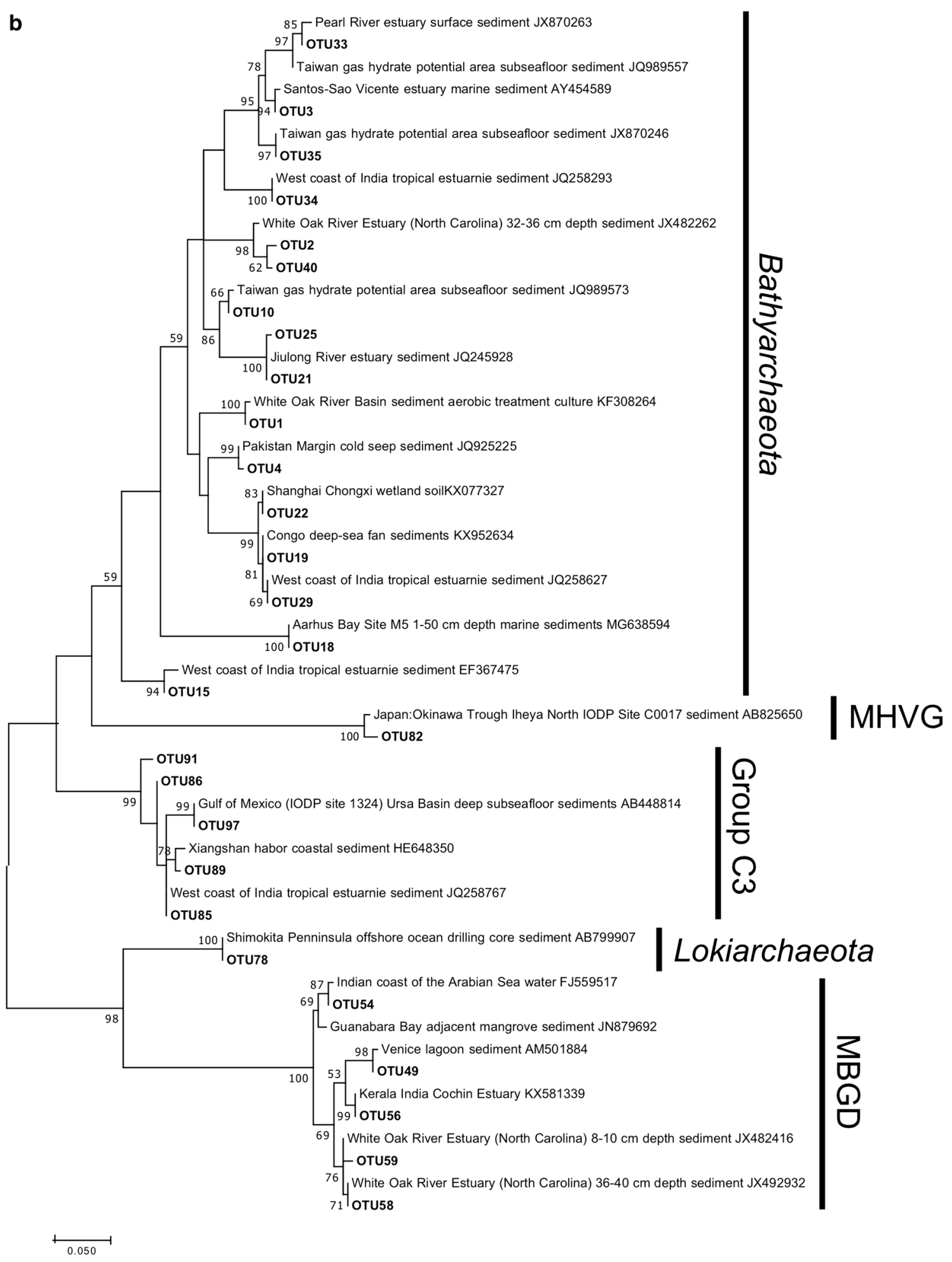

Fig. 6 continued 
hydrocarbons (An and Picardal 2014; Poritz et al. 2015). Distributional patterns of Bathyarchaeota, Group C3, Lokiarchaeota, MBGD and MHVG were similar to those of Anaerolineaceae, Dehalococcoidia and Desulfarculales (Figs. 4b, 5), suggesting that these organisms may be important for degradation of recalcitrant organic matter as well. Specifically, most of them showed preferences on marine-algae derived organic matter (higher $\delta^{13} \mathrm{C}_{\mathrm{TOC}}$ values) and humic-like FDOM (C1 and C2) (Fig. 5). Closely matched queries of $\mathrm{C} 1$ and $\mathrm{C} 2$ in OpenFluor database were identified from the dark ocean, Artic seawater and sedimentary pore water (Catala et al. 2015; Chen et al. 2016, 2018). These components may accumulate from degradation of organic matter (Chen et al. 2016) and appear to be refractory with turnover times of more than 400 years (Catala et al. 2015). Nevertheless, humic-like FDOM with high molecular weight and highly aromatic can also be bioavailable (Tfaily et al. 2018). In this study, the enriched refractory humic-like FDOM in deep layers was concurrent with the increases of archaeal relative abundance as well as Bathyarchaeal biomass.

Bathyarchaeota, Group C3 and MBGD have the potential in degradation of various substrates such as detrital protein, polymeric carbohydrates and fatty acids/ aromatic compounds as well as acetogenesis or methane/short alkane metabolisms (Evans et al. 2015; Lazar et al. 2016; Lloyd et al. 2013; Meng et al. 2014; Wang et al. 2019; Zhou et al. 2018). It has been shown that Bathyarchaeota can grow on lignin as an energy source through enrichment cultivation (Yu et al. 2018). Briefly, the archaeal groups, possibly similar to Anaerolineaceae, Dehalococcoidia and Desulfarculales, appear to use various surviving strategies in low-energy deep layers and grow on complicated organic compounds.

Overall, our study demonstrated that functional bacterial groups (e.g., SRB) dominate in redox processes in the labile-carbon-rich upper layers such as metal oxides reduction zones and sulfate reduction zones, while archaeal groups become more competitive in deep layers involved in degradation of recalcitrant organic compounds in the anaerobic remineralization processes (excluding methane-related metabolism). In organiccarbon-rich environments, bacteria can maximize the energy availability with diverse metabolic capacities (Valentine 2007), allowing them to use a wide range of electron acceptors $\left(\mathrm{NO}_{3}{ }^{-}\right.$, metal oxides and $\left.\mathrm{SO}_{4}{ }^{2-}\right)$. Gamma- and Deltaproteobacteria tend to be most abundant in the upper layers and correlated with sulfate concentrations (Oni et al. 2015a). As labile substrates consumed, archaeal and bacterial groups able to degrade recalcitrant compound become dominant in deep layers (Oni et al. 2015b), possibly relying on fermentation and acetogenesis to survive in deep subsurface (He et al. 2016; Lazar et al. 2016).

In summary, the microbial community structure showed depth variations in the Pearl River estuarine sediments, which may be coupled with profiles of $\mathrm{SO}_{4}{ }^{2+}$, $\mathrm{NH}_{4}{ }^{+}$, dissolved $\mathrm{Fe}, \delta^{13} \mathrm{C}_{\mathrm{TOC}}$, or humic-like FDOM. Bacterial and archaeal populations showed different distributional patterns in terms of relative abundance and absolute abundance. Bacterial groups including Desulfobacterales, Syntrophobacterales and Gammaproteobacteria showed strong positive correlations to $\mathrm{SO}_{4}{ }^{2-}$, and dominated in remineralization of possibly labile organic matter in the upper layers. Chloroflexi and most archaeal populations preferred deep layers and showed close positive correlations with $\mathrm{NH}_{4}{ }^{+}, \delta^{13} \mathrm{C}_{\mathrm{TOC}}$ and humic-like FDOM, suggesting their participation in degradation of recalcitrant organic matter. Archaea exhibited a weaker response to electron acceptor gradients, but a better use of humic-like FDOM. In future research, detailed analyses of organic matter composition and enrichment of archaeal species in marine sediments would be necessary to delineate the processes of organic matter utilization in archaea. This study enhances our understanding of the distribution of microbial populations and offers clues for uncovering the roles of bacteria and archaea in biogeochemical cycles in the sediments of the estuarine environment.

\section{Supplementary information}

Supplementary information accompanies this paper at https://doi. org/10.1186/s13568-020-0950-y.

Additional file 1: Table S1. Primer used in qPCR amplification.

Additional file 2: Fig. S1. Keeling plot of $\delta^{13} C_{D I C}$ vs. 1/DIC from pore water analysis. Fig. S2. Shannon diversity index curves of sediment core from PRE. Each curve represents a sample (total 38 samples) from the core.

Additional file 3: Table S2. Fluorescence spectral characteristics of three kinds of components.

Additional file 4: Table S3. Annotations of top 100 OTUs belonging to archaeal and bacterial groups, respectively.

\section{Acknowledgements}

Thanks are due to the RN Shiyan 3 of South China Sea Institute of Oceanology, Chinese Academy of Sciences. The authors would like to acknowledge contributions from Professor Zijun Wu who gave the advices on sampling for geochemistry analysis and Dengxun Lai for his help in sequencing data analysis.

\section{Funding}

This work was supported by the Laboratory for Marine Geology, Qingdao National Laboratory for Marine Science and Technology, Grant No. MGQNLM-TD201810, the National Natural Science Foundation, Grant Nos. $41776134,91851210,41530105$, National Key R\&D Program of China, Grant No. 2018YFA0605800, and the Shenzhen Key Laboratory of Marine Archaea Geo-Omics, Southern University of Science and Technology, Grant No. ZDSYS201802081843490. 


\section{Ethics approval and consent to participate}

This article does not contain any studies with human participants or animals performed by any of the authors.

\section{Competing interests}

The authors declare that they have no competing interests.

\section{Author details \\ 1 State Key Laboratory of Marine Geology, Tongji University, Shanghai, China. 2 Shenzhen Key Laboratory of Marine Archaea Geo-Omics, Department of Ocean Science and Engineering, Southern University of Science and Tech- nology, Shenzhen, China. ${ }^{3}$ Laboratory for Marine Geology, Qingdao National Laboratory for Marine Science and Technology, Qingdao, China.}

Received: 2 January 2020 Accepted: 6 January 2020

Published online: 22 January 2020

\section{References}

Algora C, Vasileiadis S, Wasmund K, Trevisan M, Krüger M, Puglisi E, Adrian L (2015) Manganese and iron as structuring parameters of microbial communities in Arctic marine sediments from the Baffin Bay. FEMS Microbiol Ecol. https://doi.org/10.1093/femsec/fiv056

An TT, Picardal FW (2014) Desulfocarbo indianensis gen. nov., sp. nov., a benzoate-oxidizing, sulfate-reducing bacterium isolated from water extracted from a coal bed. Int J Syst Evol Microbiol 64(Pt 8):2907-2914. https://doi. org/10.1099/ijs.0.064873-0

Baker BJ, Saw JH, Lind AE, Lazar CS, Hinrichs KU, Teske AP, Ettema TJ (2016) Genomic inference of the metabolism of cosmopolitan subsurface Archaea, Hadesarchaea. Nat Microbiol 1:16002. https://doi.org/10.1038/ nmicrobiol.2016.2

Biddle JF, Lipp JS, Lever MA, Lloyd KG, Sorensen KB, Anderson R, Fredricks HF, Elvert M, Kelly TJ, Schrag DP, Sogin ML, Brenchley JE, Teske A, House CH, Hinrichs KU (2006) Heterotrophic archaea dominate sedimentary subsurface ecosystems off Peru. Proc Natl Acad Sci USA 103(10):3846-3851. https://doi.org/10.1073/pnas.0600035103

Burdige DJ (2011) Estuarine and coastal sediments_coupled biogeochemical cycling. In: Wolanski E, McLusky D (eds) Treatise on estuarine and coastal science. Waltham, MA: Academic Press, pp 279-316. https://doi. org/10.1016/b978-0-12-374711-2.00511-8

Cai WJ (2011) Estuarine and coastal ocean carbon paradox: $\mathrm{CO}_{2}$ sinks or sites of terrestrial carbon incineration? Ann Rev Mar Sci 3:123-145. https://doi. org/10.1146/annurev-marine-120709-142723

Caporaso JG, Lauber CL, Walters WA, Berg-Lyons D, Huntley J, Fierer N, Owens SM, Betley J, Fraser L, Bauer M, Gormley N, Gilbert JA, Smith G, Knight R (2012) Ultra-high-throughput microbial community analysis on the Illumina HiSeq and MiSeq platforms. ISME J 6(8):1621-1624. https://doi. org/10.1038/ismej.2012.8

Catala TS, Reche I, Fuentes-Lema A, Romera-Castillo C, Nieto-Cid M, OrtegaRetuerta E, Calvo E, Alvarez M, Marrase C, Stedmon CA, Alvarez-Salgado XA (2015) Turnover time of fluorescent dissolved organic matter in the dark global ocean. Nat Commun 6:5986. https://doi.org/10.1038/ncomm s6986

Chen M, Kim JH, Nam SI, Niessen F, Hong WL, Kang MH, Hur J (2016) Production of fluorescent dissolved organic matter in Arctic Ocean sediments. Sci Rep 6:39213. https://doi.org/10.1038/srep39213

Chen M, Jung J, Lee YK, Hur J (2018) Surface accumulation of low molecular weight dissolved organic matter in surface waters and horizontal off-shelf spreading of nutrients and humic-like fluorescence in the Chukchi Sea of the Arctic Ocean. Sci Total Environ 639:624-632. https://doi.org/10.1016/j. scitotenv.2018.05.205

Clarke KR, Gorley RN (2006) Primer v6: user manual/tutorial (plymouth routines in multivariate ecological research). PRIMER-E, Plymouth

Coble PG (1996) Characterization of marine and terrestrial DOM in seawater using excitation-emission matrix spectroscopy. Mar Chem 51(4):325-346. https://doi.org/10.1016/0304-4203(95)00062-3

Dang H, Zhou H, Yang J, Ge H, Jiao N, Luan X, Zhang C, Klotz MG (2013) Thaumarchaeotal signature gene distribution in sediments of the northern South China Sea: an indicator of the metabolic intersection of the marine carbon, nitrogen, and phosphorus cycles? Appl Environ Microbiol 79(7):2137-2147. https://doi.org/10.1128/AEM.03204-12

Dickens GR, Koelling M, Smith DC, Schnieders L (2007) Rhizon sampling of pore waters on scientific drilling expeditions: an example from the IODP Expedition 302, Arctic Coring Expedition (ACEX). Sci Drill 4:22-25. https:// doi.org/10.2204/iodp.sd.4.08.2007

Evans PN, Parks DH, Chadwick GL, Robbins SJ, Orphan VJ, Golding SD, Tyson GW (2015) Methane metabolism in the archaeal phylum Bathyarchaeota revealed by genome-centric metagenomics. Science 350(6259):434. https://doi.org/10.1126/science.aac7745

Froelich PN, Klinkhammer GP, Bender ML, Luedtke NA, Heath GR, Cullen D, Dauphin P, Hammond D, Hartman B, Maynard V (1979) Early oxidation of organic matter in pelagic sediments of the eastern equatorial Atlantic: suboxic diagenesis. Geochim Cosmochim Acta 43(7):1075-1090. https:// doi.org/10.1016/0016-7037(79)90095-4

Gagen EJ, Huber H, Meador T, Hinrichs KU, Thomm M (2013) Novel cultivationbased approach to understanding the miscellaneous crenarchaeotic group (MCG) archaea from sedimentary ecosystems. Appl Environ Microbiol 79(20):6400-6406. https://doi.org/10.1128/AEM.02153-13

He Y, Li M, Perumal V, Feng X, Fang J, Xie J, Sievert SM, Wang F (2016) Genomic and enzymatic evidence for acetogenesis among multiple lineages of the archaeal phylum Bathyarchaeota widespread in marine sediments. Nat Microbiol 1(6):16035. https://doi.org/10.1038/nmicrobiol.2016.35

Imachi H, Nobu MK, Nakahara N, Morono Y, Ogawara M, Takaki Y, Takano Y, Uematsu K, Ikuta T, Ito M (2019) Isolation of an archaeon at the prokaryote-eukaryote interface. bioRxiv:726976. http://dx.doi.org/10.1101/72697 6

Inagaki F, Nunoura T, Nakagawa S, Teske A, Lever M, Lauer A, Suzuki M, Takai K, Delwiche M, Colwell FS, Nealson KH, Horikoshi K, D'Hondt S, Jorgensen BB (2006) Biogeographical distribution and diversity of microbes in methane hydrate-bearing deep marine sediments on the Pacific Ocean Margin. Proc Natl Acad Sci USA 103(8):2815-2820. https://doi.org/10.1073/ pnas.0511033103

Jiang L, Zheng Y, Peng X, Zhou H, Zhang C, Xiao X, Wang F (2009) Vertical distribution and diversity of sulfate-reducing prokaryotes in the Pearl River estuarine sediments, Southern China. FEMS Microbiol Ecol 70(2):93-106. https://doi.org/10.1111/j.1574-6941.2009.00758.x

Jiang L, Zheng Y, Chen J, Xiao X, Wang F (2011) Stratification of archaeal communities in shallow sediments of the Pearl River Estuary, Southern China. Antonie Van Leeuwenhoek 99(4):739-751. https://doi.org/10.1007/s1048 2-011-9548-3

Jorgensen SL, Hannisdal B, Lanzen A, Baumberger T, Flesland K, Fonseca R, Ovreas L, Steen $I H$, Thorseth $I H$, Pedersen RB, Schleper C (2012) Correlating microbial community profiles with geochemical data in highly stratified sediments from the Arctic Mid-Ocean Ridge. Proc Natl Acad Sci USA 109(42):E2846-E2855. https://doi.org/10.1073/pnas.1207574109

Kallmeyer J, Pockalny R, Adhikari RR, Smith DC, D’Hondt S (2012) Global distribution of microbial abundance and biomass in subseafloor sediment. Proc Natl Acad Sci USA 109(40):16213-16216. https://doi.org/10.1073/ pnas.1203849109

Kubo K, Lloyd KG, Biddle JF, Amann R, Teske A, Knittel K (2012) Archaea of the miscellaneous crenarchaeotal group are abundant, diverse and widespread in marine sediments. ISME J 6(10):1949-1965. https://doi. org/10.1038/ismej.2012.37

Kumar S, Stecher G, Tamura K (2016) MEGA7: molecular evolutionary genetics analysis version 7.0 for bigger datasets. Mol Biol Evol 33(7):1870-1874. https://doi.org/10.1093/molbev/msw054

Lai MC, Hung CC, Ding JY, Wu SY, Lai SJ, Wu CY (2011) Prokaryotic community structure of potenial gas hydrate bearing sediments from the Good Weather Ridge, SW Taiwan. In: Proceedings of the 7th international conference on gas hydrates (ICGH 2011). Edinburgh, Scotland, United Kingdom

Lazar CS, Biddle JF, Meador TB, Blair N, Hinrichs KU, Teske AP (2015) Environmental controls on intragroup diversity of the uncultured benthic archaea of the miscellaneous crenarchaeotal group lineage naturally enriched in anoxic sediments of the White Oak River estuary (North Carolina, USA). Environ Microbiol 17(7):2228-2238. https://doi. org/10.1111/1462-2920.12659

Lazar CS, Baker BJ, Seitz K, Hyde AS, Dick GJ, Hinrichs KU, Teske AP (2016) Genomic evidence for distinct carbon substrate preferences and ecological niches of 
Bathyarchaeota in estuarine sediments. Environ Microbiol 18(4):1200-1211. https://doi.org/10.1111/1462-2920.13142

Lazar CS, Baker BJ, Seitz KW, Teske AP (2017) Genomic reconstruction of multiple lineages of uncultured benthic archaea suggests distinct biogeochemical roles and ecological niches. ISME J 11(5):1118-1129. https://doi. org/10.1038/ismej.2016.189

Liang B, Wang LY, Mbadinga SM, Liu JF, Yang SZ, Gu JD, Mu BZ (2015) Anaerolineaceae and Methanosaeta turned to be the dominant microorganisms in alkanes-dependent methanogenic culture after long-term of incubation. AMB Express 5(1):117. https://doi.org/10.1186/s13568-015-0117-4

Lipp JS, Morono Y, Inagaki F, Hinrichs KU (2008) Significant contribution of archaea to extant biomass in marine subsurface sediments. Nature 454(7207):991-994. https://doi.org/10.1038/nature07174

Lloyd KG, Schreiber L, Petersen DG, Kjeldsen KU, Lever MA, Steen AD, Stepanauskas R, Richter M, Kleindienst S, Lenk S, Schramm A, Jorgensen BB (2013) Predominant archaea in marine sediments degrade detrital proteins. Nature 496(7444):215-218. https://doi.org/10.1038/nature12033

Meng J, Xu J, Qin D, He Y, Xiao X, Wang F (2014) Genetic and functional properties of uncultivated MCG archaea assessed by metagenome and gene expression analyses. ISME J 8(3):650-659. https://doi.org/10.1038/ismej.2013.174

Monteverde D, Sylvan J, Suffridge C, Baronas JJ, Fichot E, Fuhrman J, Berelson WM, Sanudo-Wilhelmy S (2018) Distribution of extracellular flavins in a coastal marine basin and their relationship to redox gradients and microbial community members. Environ Sci Technol. https://doi.org/10.1021/acs. est.8b02822

Murphy KR (2011) A note on determining the extent of the water Raman peak in fluorescence spectroscopy. Appl Spectrosc 65(2):233-236. https://doi. org/10.1366/10-06136

Nunoura T, Nishizawa M, Hirai M, Shimamura S, Harnvoravongchai P, Koide O, Morono Y, Furkui T, Inagaki F, Miyazaki J, Takaki Y, Takai K (2018) Microbial diversity in sediments from the bottom of the Challenger Deep, the Mariana Trench. Microbes Environ. https://doi.org/10.1264/jsme2.me17194

Oni O, Miyatake T, Kasten S, Richter-Heitmann T, Fischer D, Wagenknecht L, Kulkarni A, Blumers M, Shylin SI, Ksenofontov V, Costa BF, Klingelhofer G, Friedrich MW (2015a) Distinct microbial populations are tightly linked to the profile of dissolved iron in the methanic sediments of the Helgoland mud area, North Sea. Front Microbiol 6:365. https://doi.org/10.3389/fmicb.2015.00365

Oni O, Schmidt F, Miyatake T, Kasten S, Witt M, Hinrichs KU, Friedrich MW (2015b) Microbial communities and organic matter composition in surface and subsurface sediments of the Helgoland mud area, North Sea. Front Microbiol 6:1290. https://doi.org/10.3389/fmicb.2015.01290

Orsi WD, Edgcomb VP, Christman GD, Biddle JF (2013) Gene expression in the deep biosphere. Nature 499(7457):205-208. https://doi.org/10.1038/natur e12230

Pan J, Chen Y, Wang Y, Zhou Z, Li M (2019) Vertical distribution of bathyarchaeotal communities in mangrove wetlands suggests distinct niche preference of Bathyarchaeota Subgroup 6. Microb Ecol 77(2):417-428. https://doi. org/10.1007/s00248-018-1309-7

Poritz M, Schiffmann CL, Hause G, Heinemann U, Seifert J, Jehmlich N, von Bergen M, Nijenhuis I, Lechner U (2015) Dehalococcoides mccartyi strain DCMB5 respires a broad spectrum of chlorinated aromatic compounds. Appl Environ Microbiol 81 (2):587-596. https://doi.org/10.1128/AEM.02597-14

Qiao Y, Liu J, Zhao M, Zhang XH (2018) Sediment depth-dependent spatial variations of bacterial communities in mud deposits of the Eastern China Marginal Seas. Front Microbiol 9:1128. https://doi.org/10.3389/fmicb.2018.01128

Roy H, Kallmeyer J, Adhikari RR, Pockalny R, Jorgensen BB, D'Hondt S (2012) Aerobic microbial respiration in 86-million-year-old deep-sea red clay. Science 336(6083):922-925. https://doi.org/10.1126/science.1219424

Schmid M, Walsh K, Webb R, Rijpstra WI, van de Pas-Schoonen K, Verbruggen MJ, Hill T, Moffett B, Fuerst J, Schouten S, Sinninghe Damsté JS, Harris J, Shaw P, Jetten M, Strous M (2003) Candidatus "Scalindua brodae", sp. nov., Candidatus "Scalindua wagneri", sp. nov., two new species of anaerobic ammonium oxidizing bacteria. Syst Appl Microbiol 26(4):529-538. https:// doi.org/10.1078/072320203770865837

Segata N, Izard J, Waldron L, Gevers D, Miropolsky L, Garrett WS, Huttenhower C (2011) Metagenomic biomarker discovery and explanation. Genome Biol 12(6):R60. https://doi.org/10.1186/gb-2011-12-6-r60

Seitz KW, Lazar CS, Hinrichs KU, Teske AP, Baker BJ (2016) Genomic reconstruction of a novel, deeply branched sediment archaeal phylum with pathways for acetogenesis and sulfur reduction. ISME J 10(7):1696-1705. https://doi. org/10.1038/ismej.2015.233

Seitz KW, Dombrowski N, Eme L, Spang A, Lombard J, Sieber JR, Teske AP, Ettema TJG, Baker BJ (2019) Asgard archaea capable of anaerobic hydrocarbon cycling. Nat Commun 10(1):1822. https://doi.org/10.1038/s41467-01909364-X

Shannon P, Markiel A, Ozier O, Baliga NS, Wang JT, Ramage D, Amin N, Schwikowski B, Ideker T (2003) Cytoscape a software environment for integrated models of biomolecular interaction networks. Genome Res 13:2498-2504. https://doi.org/10.1101/gr.1239303

Sousa FL, Neukirchen S, Allen JF, Lane N, Martin WF (2016) Lokiarchaeon is hydrogen dependent. Nat Microbiol. https://doi.org/10.1038/nmicrobiol.2016.34

Starnawski P, Bataillon T, Ettema TJ, Jochum LM, Schreiber L, Chen X, Lever MA, Polz MF, Jorgensen BB, Schramm A, Kjeldsen KU (2017) Microbial community assembly and evolution in subseafloor sediment. Proc Natl Acad Sci USA 114(11):2940-2945. https://doi.org/10.1073/pnas.1614190114

Stedmon CA, Markager S (2005) Resolving the variability in dissolved organic matter fluorescence in a temperate estuary and its catchment using PARAFAC analysis. Limnol Oceanogr 50(2):686-697. https://doi.org/10.4319/ lo.2005.50.2.0686

Tfaily MM, Wilson RM, Cooper WT, Kostka JE, Hanson P, Chanton JP (2018) Vertical stratification of peat pore water dissolved organic matter composition in a Peat Bog in Northern Minnesota. J Geophys Res Biogeosci 123(2):479-494. https://doi.org/10.1002/2017jg004007

Thauer RK, Kaster AK, Seedorf H, Buckel W, Hedderich R (2008) Methanogenic archaea: ecologically relevant differences in energy conservation. Nat Rev Microbiol 6(8):579-591. https://doi.org/10.1038/nrmicro1931

Ushiki N, Jinno M, Fujitani H, Suenaga T, Terada A, Tsuneda S (2017) Nitrite oxidation kinetics of two Nitrospira strains: the quest for competition and ecological niche differentiation. J Biosci Bioeng 123(5):581-589. https://doi. org/10.1016/j.jbiosc.2016.12.016

Valentine DL (2007) Opinion: adaptations to energy stress dictate the ecology and evolution of the archaea. Nat Rev Microbiol 5(4):316. https://doi. org/10.1038/nrmicro1619

Vanwonterghem I, Evans PN, Parks DH, Jensen PD, Woodcroft BJ, Hugenholtz P, Tyson GW (2016) Methylotrophic methanogenesis discovered in the archaeal phylum Verstraetearchaeota. Nat Microbiol 1:16170. https://doi. org/10.1038/nmicrobiol.2016.170

Walsh EA, Kirkpatrick JB, Pockalny R, Sauvage J, Spivack AJ, Murray RW, Sogin ML, D'Hondt S (2016) Relationship of bacterial richness to organic degradation rate and sediment age in subseafloor sediment. Appl Environ Microbiol 82(16):4994-4999. https://doi.org/10.1128/AEM.00809-16

Wang Y, Wegener G, Hou J, Wang F, Xiao X (2019) Expanding anaerobic alkane metabolism in the domain of archaea. Nat Microbiol 4(4):595-602. https:// doi.org/10.1038/s41564-019-0364-2

Wu J, Calvert S, Wong C, Whitney F (1999) Carbon and nitrogen isotopic composition of sedimenting particulate material at Station Papa in the subarctic northeast Pacific. Deep Sea Res Part II 46(11-12):2793-2832. https://doi. org/10.1016/S0967-0645(99)00084-3

YuT, Liang Q, Niu M, Wang F (2017) High occurrence of Bathyarchaeota (MCG) in the deep-sea sediments of South China Sea quantified using newly designed PCR primers. Environ Microbiol Rep 9(4):374-382. https://doi. org/10.1111/1758-2229.12539

Yu T, Wu W, Liang W, Lever MA, Hinrichs KU, Wang F (2018) Growth of sedimentary Bathyarchaeota on lignin as an energy source. Proc Natl Acad Sci USA. https://doi.org/10.1073/pnas.1718854115

Zhang W, Ding W, Yang B, Tian R, Gu S, Luo H, Qian PY (2016) Genomic and transcriptomic evidence for carbohydrate consumption among microorganisms in a cold seep brine pool. Front Microbiol 7:1825. https://doi. org/10.3389/fmicb.2016.01825

Zhou Z, Liu Y, Lloyd KG, Pan J, Yang Y, Gu JD, Li M (2018) Genomic and transcriptomic insights into the ecology and metabolism of benthic archaeal cosmopolitan, Thermoprofundales (MBG-D archaea). ISME J. https://doi. org/10.1038/s41396-018-0321-8

\section{Publisher's Note}

Springer Nature remains neutral with regard to jurisdictional claims in published maps and institutional affiliations. 